\title{
Wioletta PIETRUSZKA
}

Wyższa Szkoła Humanistyczno-Przyrodnicza w Sandomierzu

\section{WZÓR POCZCIWEGO MLODZIEŃCA KREOWANY W ŻYWOCIE MIKOLAJA REJA}

Żywot człowieka poczciwego to jedna $\mathrm{z}$ ośmiu części obszernego utworu zatytułowanego Źwierciadło albo kształt, $w$ którym każdy stan snadnie się może swym sprawom jako we zwierciadle przypatrzyć. Niektórzy badacze twierdzą, że wbrew tytułowej formule, mógł się $w$ nim przejrzeć tylko stan szlachecki, on to bowiem jest bohaterem Rejowych rozważań ${ }^{1}$. Jednak wiele fragmentów Żywota dotyczy człowieka w ogóle, a pouczenia i przykłady obrazujące kolejne tezy pisarza mogłyby funkcjonować jako uniwersalne. Utwór zawiera wprawdzie opis wzorca osobowego szlachcica-ziemianina, człowieka żyjącego na wsi $\mathrm{w}$ harmonii $\mathrm{z}$ otaczającym go światem, autor buduje jednak w Żywocie przede wszystkim wzorcową biografię człowieka poczciwego, wskazując czytelnikowi wartości, uroki i pożytki płynące $z$ prawego, statecznego, uczciwego i zgodnego $\mathrm{z}$ naturą życia. Rejowa biografia typowego szlachcica-ziemianina ma porządek chronologiczny, który wyznaczają trzy etapy: młodość, wiek średni oraz starość. $W$ ten sposób pisarz stworzył pełny obraz życia ludzkiego.

Celem moich rozważań jest, po pierwsze, próba odtworzenia na podstawie utworu Mikołaja Reja wizerunku poczciwego młodzieńca, a zatem skoncentruję swoją uwagę na wstępnych latach życia człowieka, które są przecież niezwykle istotne dla kształtowania jego osobowości. Po drugie, spróbuję ustalić, za pomocą jakich środków językowych usiłował pisarz wpłynąć na myślenie i postępowanie czytelnika.

1 Por. A. Brückner, Wstęp, [w:] M. Rej, Pisma prozq i wierszem, Kraków 1921, s. 29. Por. także I. Chrzanowski, Historia literatury niepodległej Polski, Warszawa 1971, s. 120. 
Żywot człowieka poczciwego wśród wielu badaczy uchodzi za utwór parenetyczny. Podkreślić należy, że terminy: parenetyka czy pareneza nie należały do zasobu terminologii literatury staropolskiej. Jak wyjaśnia Ziomek: „literatura parenetyczna to dzieła o charakterze dydaktyczno-moralistycznym przedstawiające godne naśladowania wzorce osobowe i zalecające określone sposoby i cele właściwego postępowania. Nazwa pochodzi od gr. parainéo - namawiam, zachęcam"2.

A zatem ideą literatury parenetycznej było tworzenie wzoru, a wzór zachęca lub powinien zachęcać do naśladownictwa ${ }^{3}$. Takim wzorem miał stać się szlachcic-ziemianin, człowiek poczciwy. Należałoby się zastanowić, jakimi cechami się charakteryzował. Zanim przyjrzymy się bliżej kreowanemu przez autora wizerunkowi, oglądowi poddajmy przymiotnik poczciwy. I tak w Stowniku polszczyzny XVI wieku znajdujemy rozbudowane definicje słowa, które potwierdzają częste występowanie tego leksemu $\mathrm{w}$ interesującym nas okresie. A zatem, zgodnie $\mathrm{z}$ opisem leksykograficznym, poczciwy (poćciwy) i potciwy to:

1. 'Peten zalet moralnych, cnotliwy, uczciwy, przyzwoity, pobożny'.

2. 'Przynoszacy cześć, honor, będacy oznaka, dowodem, efektem honorowych czynow, godny szacunku, chlubny, zaszczytny, honorowy'.

3. 'Godny szacunku'.

4. 'Życzliwy, wyrażajacy dobra opinię o kimś'.

2 J. Ziomek, Parenetyczna literatura, [w:] Literatura polska. Przewodnik encyklopedyczny, t. II, pod red. Cz. Hernasa, Warszawa 1985, s. 146. Inne źródła podają, że pareneza to „zdanie, zwrot, przemówienie zawierające myśl umoralniającą; napomnienie", a teksty parenetycz$n e$ to "utwory przedstawiające wzór postępowania i pożądane cechy osobowe człowieka pełniącego taką czy inną funkcję społeczną (...)." Por. Literatura $i$ nauka o języku. Encyklopedia szkolna, pod red. A. Z. Makowieckiego, Warszawa 1999, s. 374. Autorzy Stownika terminów literackich podobnie wyjaśniają pojęcie literatury parenetycznej, podkreślając propagowanie wzorców postępowania związanych $\mathrm{z}$ pełnieniem określonych ról społecznych. Por. M. Głowiński, T. Kostkiewiczowa, A. Okopień-Sławińska, Słownik terminow literackich, Wrocław 2002, s. 373. Dziechcinska natomiast zwraca uwagę na dwa zagadnienia: parenetyczną postawę i parenetyczną literaturę, które się wzajemnie przenikają i uzupełniają. Autorka pisze: „Literatura parenetyczna to typ piśmiennictwa, w którym postawa taka [parenetyczna (a więc najogólniej biorąc - pouczająca)] dochodziła do głosu w sposób szczególnie dobitny, a którego nadrzędnym zadaniem było propagowanie określonych wzorów osobowych za pomocą specjalnych technik literackich." Por. H. Dziechcinska, Parenetyka, [w:] Słownik literatury staropolskiej, pod red.T. Michałowskiej, Wrocław 1990, s. 619.

3 M. Ossowska tak pisze: „Wzór osobowy można rozumieć prowizorycznie jako postać realną lub fikcyjną, która zachęca do naśladowania, sciślej, wzorem osobowym dla danej jednostki czy grupy społecznej jest postać ludzka, która powinna być lub jest faktycznie dla tej jednostki przedmiotem aspiracji." Por. M. Ossowska, Etos rycerski $i$ jego odmiany, Warszawa 1973, s. 12. 
5. 'Odpowiednio dobry, godny, godziwy, stosowny, przyzwoity'.

6. 'Dobry $w$ sensie ogolnikowym'4.

Mamy tu więc do czynienia z pojęciem o bardzo szerokiej semantyce, które w XVI wieku, najogólniej rzecz ujmując, oznaczało wzór cnót. Dziś możemy mówić o semantycznym zawężeniu, ponieważ określenie poczciwy stosujemy najczęściej jako synonim leksemów: życzliwy, dobroduszny, lagodny, zacny ${ }^{5}$ i używamy raczej rzadko, co potwierdza także fakt, iż jest ono zaliczane do „wyrazów zapomnianych” czy „polszczyzny zaginionej"6. Jednak w zasobie językowym Reja jest to leksem kluczowy, powtarzający się wielokrotnie $\mathrm{w}$ różnej formie: poczciwość - rzeczownik, poczciwy - przymiotnik, poczciwie - przysłówek.

Celem życia człowieka - zdaniem autora Żywota - powinna być poczciwość, czyli umiejętność osiągnięcia spokoju wewnętrznego, wynikającego z odnalezienia własnego miejsca na ziemi. Człowiek poczciwy to ten, który nieustannie kształtuje swój charakter, dba o to, by zalety przeważały nad wadami. Ale poczciwy to przede wszystkim ktoś, kto kieruje się zasadą tzw. złotego środka, czyli wykazuje umiar i rozsądek. Rej zachęcał także do życia zgodnego z prawami natury, które miało nie tylko cieszyć, ale z którego dałoby się czerpać ogólnie pojętą mądrość życiową.

Najważniejszymi cechami charakteru człowieka poczciwego są: cnotliwość, uczciwość, sprawiedliwość, szlachetność, rozwaga, skromność, pracowitość i umiłowanie ojczyzny ${ }^{7}$. To one bowiem - zdaniem Jakubowskiego - „czynią zeń życzliwego sąsiada, dobrego pana, wymagającego, ale łagodnego w stosunku do poddanych, szanowanego męża i ojca rodziny" ${ }^{\prime \prime}$ a zatem człowieka zasługującego na ogólny szacunek i uznanie innych, czyli tzw. dobrą sławę.

4 Słownik polszczyzny XVI wieku, pod red. M. R. Mayenowej, t. XXV, Warszawa 1997, s. 262-268. We współczesnych słownikach znaleźć można następujące objaśnienie: poczci$w y-1$. 'życzliwy $w$ stosunku do ludzi, skłonny do pomagania innym, lagodny, przyjazny, zacny'; 2 'wyrażający takie cechy'. Por. np. Mały słownik języka polskiego, pod red. E. Sobol, Warszawa 1995, s. 640. Inni podają: „poczciwy - czcigodny, dostojny, chwalebny, honorowy, zacny, zaszczytny." Por. S. Reczek, Podręczny słownik dawnej polszczyzny, Wrocław 1968, s. 331.

5 Za: Słownik języka polskiego, pod. red. M. Szymczaka, Warszawa 1988, t. 2, s. 720.

6 Por. Mały słownik zaginionej polszczyzny, pod red. F. Wysockiej, Kraków 2003, s. 226 oraz K. Holly, A. Żołtak, Słownik wyrazow zapomnianych, czyli słownictwo naszych lektur, Warszawa 2001, s. 270.

7 Źle pojmowany patriotyzm zarzucał Rejowi m.in. I. Chrzanowski, op. cit., s. 130.

8 Literatura polska od sredniowiecza do pozytywizmu, pod red. J. Z. Jakubowskiego, Warszawa 1975, s. 93. 
Kreując wizerunek poczciwego młodzieńca, pisarz szczególną uwagę zwracał na wychowanie człowieka oraz wykształcenie, $\mathrm{w}$ tym edukacje domową i podróże, a także służbę - na dworze i w wojsku.

Bardzo ważne było dla Reja odpowiednie wychowanie dziecka. Uważał on bowiem, że dzięki należytemu podejściu oraz właściwym metodom postępowania można poskromić naturę i zmodyfikować temperament młodego człowieka. I choć zajmowanie się małym dzieckiem przypisywał matce, to przecież uwzględniał także „instytucję" mamki, od której wymagał nie tylko umiejętności pedagogicznych, ale i przymiotów usposobienia. Winna to być osoba: (...) przyrodzenia dobrego, obyczajow uczciwych, która aby wnet obaczała ku czemu by się przyrodzenie dzieciatka onego ściqgało, jeśli ku gniewu, jeśli ku ospalstwu, jeśli ku zbytniemu płaczowi, albo lamentowi, tedy go po trosze nie gniewem, nie fukiem, ale jakoby igraniem a nadobnym $i$ tagodnym upominaniem pohamować... (s. 32)9.

Dalsze wychowanie i edukację dziecka powierzał nauczycielowi. Wypada podkreślić, że pisarz niewiele uwagi poświęcił szkole, ponieważ był zwolennikiem wychowania prywatnego, toteż rodzicom proponował przyjęcie do domu cnotliwego, statecznego, trzeźwego, a pomiernego preceptora. W takim systemie wychowania widział autor Żywota podwójną korzyść. Po pierwsze, dziecko byłoby jednocześnie pod kontrolą nauczyciela i rodziców. Po drugie, Rej obawiał się, aby rówieśnicy, których określił mianem sprośnych chłopięt szkolnych, nie mieli negatywnego wpływu na kształtującą się osobowość młodego człowieka.

O wartości nauki szkolnej dla szlachcica twórca wyrażał się następująco: Nie dajże się z nim $z$ młodu tamać twardymi a wichrowatymi naukami, boć mu snadnie w młodej głowie wszytko pomieszaja (...) Boć wierę gramatyka z logikq, nie wiem, i staremu by się czasem nie uprzykrzyła (s. 37). Już chociażby ten krótki fragment dowodzi, że ważniejsze od książkowej wiedzy było dla Reja doświadczenie życiowe. Badaczka twórczości Rejowej - Dziechcińska ${ }^{10}$ - utrzymuje, że 6 wczesna szlachta, skłaniając się ku życiu ziemiańskiemu, odczuwała wyraźną niechęć do humanistycznego programu kształcenia.

9 M. Rej, Żywot człowieka poczciwego, Wrocław 1956. Po cytatach umieszczam numer strony, z której pochodzi przywołany fragment.

10 Por. H. Dziechcińska, Szlachcic idealny $w$ "Żywocie człowieka poczciwego", czyli narracja perswazyjna, „Pamiętnik Literacki”, LX 1969, z. 4, s. 48. 
Wiele uwagi poświęcił twórca zagadnieniu wypraw młodych ludzi do innych krajów ${ }^{11}$, podkreślając zalety wojażowania, ale zwracając również uwagę na negatywne skutki podróży ${ }^{12}$, do których zaliczał m.in. narażanie się na kontakt ze złym towarzystwem.

Umiejętności, które powinien nabyć młodzieniec to: prowadzenie konwersacji, gra na lutni, taniec, jazda konna i posługiwanie się bronią ${ }^{13}$.

Mikołaj Rej w Żywocie stworzył więc swoistego rodzaju kodeks moralny i obyczajowy, eksponujący sprawy życia codziennego, które były mu doskonale znane. Gromadził przykłady i selekcjonował wzory postępowania, do jednych nakłaniał, inne piętnował. Podając liczne exempla stosownego zachowania, zaprezentował się jako nauczyciel-moralizator, którego zadaniem było wychowywanie młodego pokolenia.

Utwór ten stanowi przykład typowego tekstu o funkcji perswazyjnej. Perswazja rozumiana jest jako wpływanie na przekonania odbiorcy za pomocą mowy przez oddziaływanie na jego rozum, wolę i emocje. Perswazja językowa służy więc wytworzeniu w adresacie pewnego stanu przekonaniowego ${ }^{14}$. Wydaje mi się, że warto się zatem zastanowić: jakich środków językowych skutecznego przekonywania odbiorcy używał Rej? Jakie typy wypowiedzi wywierały nacisk na stan mentalny odbiorcy?

Już wybór gatunku - „Zwierciadło” (łac. speculum) decyduje o tym, iż utwór ten na wskroś przeniknięty został ideą pouczania, namawiania i zalecania. Zabiegi perswazyjne wykorzystał autor m.in. w budowaniu wzoru osobowego, za pomocą którego propagował życie stosowne dla człowieka tamtej epoki. Twórca skonstruował bowiem postać modelową, w której skupił właściwe, według niego, normy moralne. Stworzył bohate-

11 Pisał na ten temat m.in. J. S. Bystron, Dzieje obyczajow w dawnej Polsce. Wiek XVI-XVIII, t. I, Warszawa 1960, s. 85.

12 Wielu badaczy tego okresu wojaże zagraniczne młodzieży szlacheckiej ocenia krytycznie, podkreślając nikłe pożytki z nich wynikające. Por. Historia Polski, t. I, pod red. H. Łowmiańskiego, Warszawa 1965, s. 360.

13 Kwestię dotyczącą zajęć wojskowych poruszał m.in. Bystron, pisząc o obyczajach tamtego okresu: „Szlachcic jest urodzony do broni, do wojny; tłumaczono przecież wolnosć jako ścisle związaną z rycerską służbą: cnotą rycerską jest odwaga, szlachetność, bezinteresownosć. Nie wystarczało więc urodzić się szlachcicem, trzeba było jeszcze ćwiczeniem rycerskim osiągnąć poziom prawego rycerza; kto tego poziomu nie dochodzi, niegodzien jest szlacheckiego tytułu". Autor zwraca jednak uwagę na zjawisko zanikania w XVI wieku znaczącej roli umiejętności wojskowych, o których szlachta coraz częsciej jedynie rozprawiała. Por. J. S. Bystroń, op. cit., s. 149-151.

14 Por. R. Grzegorczykowa, Nowomowa a problem funkcji wypowiedzi, „Poradnik Językowy” 1985, z. 6, s. 379. 
ra godnego naśladowania, a osiągnął to dzięki umiejętnemu zastosowaniu środków językowych typowych dla funkcji perswazyjnej.

O tym, że Żywot jest swoistym wykładem moralnym, a odbiorca miał czerpać $z$ niego nauki i wskazówki, świadczą chociażby tytuł całości i tytuły zamieszczone w poszczególnych rozdziałach, które Dziechcińska nazywa za Barthesem „znakami narracyjności" ${ }^{15}$. Przywołajmy chociaż niektóre:

III 1 Jako majq rodzicy starać się o wychowanie młodych dziatek swoich $i$ jako majq rozeznawać przyrodzenie ich.

III 4 Jakiego preceptora młodym dzieciom szukać.

VI 1 Jako młody człowiek ma się do cudzych krajów przejezdzić.

VIII 4 Do domu przyjechawszy, co pan młody czynić ma.

Dla ukonkretnienia, a także udobitnienia, swego wywodu pisarz przywoływał exempla. Łącząc więc wykład z przykładem, opowiadał o czymś, co się zdarzyło i z czego czytelnik miał wyciągnąć pouczające wnioski ${ }^{16}$. Przeplatając wypowiedzi opisowo-narracyjne wypowiedziami normatywno-zalecającymi, autor dynamizował statyczne z założenia speculum.

Cechą istotną prozy Reja jest regularne stosowanie tzw. „mowy wprost", np.: patrzajże zasię...; bo patrz...; abowiem patrzaj...; a tak $i$ ty, mój mity bracie...; a tak $i$ ty, moj miły panie młody..., dzięki czemu utrzymywał on stały kontakt $\mathrm{z}$ czytelnikiem, a włączane $\mathrm{w}$ tok wywodu bezpośrednie zwroty do adresata sprawiają wrażenie prowadzenia dialogu $\mathrm{z}$ odbiorcą.

Fakt, że Rej zwracał się do konkretnych osób, można uznać za środek służący do oddziaływania na innych. Zdaniem Barańczaka funkcja perswazyjna wypowiedzi polega właśnie na „usiłowaniu uzyskania realnego wpływu na sposób myślenia lub postępowania odbiorcy $(. . .)^{\prime \prime 17}$. Odbiorca utworu ulega mechanizmowi nakłaniania między innymi poprzez bezpośrednio do niego adresowane słowa, co prowadzi do wytworzenia płaszczyzny pełnego porozumienia. I tak, gdy dziecko jest małe, adresatami słów pisarza stają się jego rodzice: Nie więżyż (nie wkładaj) mu nazbyt $z$ młodu knefliczków, bryżyczków, pstrych sukienek, jako prosięciu, bo jako się tego z młodu nauczy, tak mu się to w pamięć wbije (s. 34). Z czasem odbiorcą

15 H. Dziechciŕska, Szlachcic idealny..., op. cit., s. 53.

16 Ibidem.

17 S. Barańczak, Słowo - perswazja - kultura masowa, „Twórczośc” 1975, z. 7, s. 49. 
pouczeń Rejowych zostaje młodzieniec poczciwy: A nalazszy dobrego, cnotliwego człowieka, już się go dzierż jako muru, a przypatruj się pilno i sprawam, i postawam $i$ wszytkim postępkom jego, abyś także swe obyczaje onymiż ćwioczki jego zakowat a mocno zahartowat $w$ sobie, jakoby sie potym ni na czym nie pośliznęty (s. 77).

Stosowanie form 2 os. 1. poj. i liczne apostrofy to przejaw zażyłego związku między autorem a odbiorcą tekstu, co potwierdza tylko spostrzeżenia badaczy, którzy dowodzą, że: „aby komunikacja perswazyjna była skuteczna, musi zakładać wspólnotę horyzontu interpretacyjnego zbliżenie racji i maksymalne uzgodnienie zasad gry językowej. (...) Komunikacja perswazyjna zakłada istnienie wspólnoty: języka, reguł, a nawet celów i sposobu ich postrzegania" 18 .

Awdiejew wśród funkcji pragmatycznych wyróżnia funkcje pobudzające do określonego działania, a w ich obrębie funkcje: proponowania, prośby, rozkazu, rozstrzygnięcia, zgody, rady, wyrażenia odmowy i wyrażenia niezdecydowania ${ }^{19}$. Wydaje się, że Rej stosuje w Żywocie dwie spośród nich:

- funkcję proponowania, która może się odnosić zarówno do nadawcy i odbiorcy, jak i do samego odbiorcy, pozostawiając mu jednak dowolność postępowania. Warunkiem proponowania jest poinformowanie adresata, że wykonanie $X$ leży $w$ obopólnym interesie nadawcy i odbiorcy. Rej, tworząc wizerunek poczciwego młodzieńca, nie tylko ukazywał korzyści płynące dla osoby, która zechce go realizować, ale sam był również zainteresowany podjęciem tego działania przez czytelnika;

- funkcję rady, w której korzyść leży całkowicie po stronie odbiorcy. „Funkcja rady wyraża udzielenie przez nadawcę wskazówek do wyboru optymalnego działania odbiorcy lub innej osoby, pozostawiając jednak przy tym wolny wybór działania" ${ }^{20}$. Innymi słowy, podstawowym warunkiem pragmatycznym dla rady jest zainteresowanie odbiorcy otrzymaniem wskazówek od nadawcy, co Rej czyni szczodrze, dając szczegółowe wytyczne dotyczące m.in. pielęgnacji niemowlęcia,

18 J. Warchala, Horyzonty manipulacji: perswazja, manipulacja, interpretacja, [w:] Manipulacja $w$ języku, pod red. P. Krzyżanowskiego, P. Nowaka, Lublin 2004, s. 53.

19 Por. A. Awdiejew, Pragmatyczne podstawy interpretacji wypowiedzi, Kraków 1987, s. 107-135 .

20 Ibidem, s. 129. 
jego pożywienia, np.: a nie pieść też nazbyt przyrodzenia jego, nie żufeczkami, nie tymi wymyślonymi pieścidłki, nie winki też, a jeśli tedy barzo rzadko i mało, bo $i$ mdlejsze będzie, $i$ żołqdek czemu z młodu przywyknie, tego mu się zawżdy będzie chciało. A potym, gdy przydzie na grubsze potrawy, tedy (...) każda rzecz zaszkodzić więcej będzie mogła (s. 33).

Istotą funkcji pobudzania do działania jest typowanie przez nadawcę, w tym przypadku Reja, konkretnego odbiorcy: matki, ojca, później młodzieńca jako potencjalnego wykonawcy proponowanych poczynań.

Pragnąc wzmocnić moc oddziaływania na czytelnika, Mikołaj Rej często stosował wypowiedzi normatywne $\mathrm{z}$ predykatem modalnym typu: trzeba, np.: Bo będziesz li chciał postanowić w sobie pychę, a uźrzysz, ano jej tam więcej, toć tu bedzie trzeba [podkreślenia moje - W. P.] rozsqdku, iż to przypadek niedobry, chociaj mu się tam $i$ w ozdobnych ludzioch przypatrzysz. A tu już zasię będzieć trzeba i przeciwnegoćwiczenia, i przeciwnego towarzystwa szukać sobie (s. 78).

Cały utwór Rejowy można zamknąć w formule: Chcę, żebyś coś zrobił lub zaniechał robienia czegoś. Ta chęć skłonienia odbiorcy do podjęcia określonych działań stanowi wynik aktywnego stosunku nadawcy wobec czytelnika, co jest typowe dla imperatywów, czyli aktów mowy, w których występuje artykulacja postawy wypowiadającego wobec adresata ${ }^{21}$. Wśród stosowanych przez twórcę dyrektywów wyróżnić można nakazy lub zakazy, które charakteryzują się znaczną kategorycznością, w dużym stopniu ograniczając wybór, gdyż zakładają, że „zachowanie S [zachowanie O oczekiwane przez N] odbiorcy musi być" 22, np. Bo jesli koleryk, nie dajże mu pokarmów gorących, także i melankolikowi, bobyś jeszcze barziej podpalił onego gorqcego przyrodzenia jego. Jesliże też flegmatyk, nie dajże mu też rzeczy z przyrodzenia zazięblych, bobyś także jeszcze więcej poprawił tępości i gnuśności jego (s. 32-33). W Żywocie występują również akty nacechowane mniejszą kategorycznością, których istotą jest podpowiedź nadawcy w sytuacji niezdecydowania odbiorcy w stosunku do niezbędnego działania. Rolę taką pełnią: rady, zachęty, wskazówki, propozycje, które pozostawiają dużą dozę swobody, bo cechuje je „fakultatywność wyboru zachowań $\mathrm{O} z$ nakierowaniem na zachowanie $\mathrm{S}^{\prime 2}{ }^{23}$ np. Potym, gdy już

21 D. Bula, J. Nawacka, Próba klasyfikacji aktow mowy, „Socjolingwistyka” 1983, nr 5, s. 34-35.

22 Ibidem.

23 Ibidem. 
dzieciatko podroście, iż mu się smysty $i$ przyrodzenie lepiej stanowić będzie, starajże mu się pilno o jakiego cnotliwego, statecznego, trzeżwego, a pomiernego preceptora, aby nauki stuszne i obyczajnie poczciwe mógł z niego brać i obaczać. A nalepiejgo doma do czasu pochować, bo wżdy $i$ rodziców, i preceptora po trosze się przestrzegać będzie (s. 36-37).

Zastosowanie perswazji wpłynęło na charakter utworu, który pouczając, skłaniał do poczciwego, tj. cnotliwego, przyzwoitego, godnego szacunku życia. Rej nie prezentował się w nim jako mówca-polemista, nie zmieniał bowiem punktu widzenia, nie wysnuwał wniosków dopiero po pokazaniu różnorodnych aspektów danego zjawiska. Wręcz przeciwnie, od razu znał rozstrzygnięcia, bo głosił niepodważalne dla siebie wartości. Zabieg taki wywodził się $\mathrm{z}$ retoryki średniowiecznych kazań ${ }^{24}$.

Na zakończenie wypada dodać i to, że troska Reja o ukształtowanie wzorcowego młodzieńca nie była czymś specyficznym tylko dla niego. Miał on poprzedników zajmujących się kwestią wychowania, jak choćby: Szymona Marycjusza z Pilzna, Andrzeja Frycza Modrzewskiego, Erazma Glicznera, Stanisława Koszutskiego czy Marcina Kwiatkowskiego ${ }^{25}$. Pisarze ci jeszcze przed ukazaniem się utworu twórcy z Nagłowic zabiegali o odpowiednie wychowanie człowieka, postulując potrzebę zorganizowania właściwego systemu kształcenia umysłowego i moralnego młodego pokolenia. Już nawet pobieżny przegląd wywodów, zamieszczonych w Księdze I Żywota człowieka poczciwego, pozwala stwierdzić, że autor nie stworzył oryginalnej teorii, a jego opinie miały silny związek z poglądami wyrażonymi przez przywołanych autorów.

Sądzę, iż nie popełnię nadużycia, jeśli Rejowy utwór nazwę niemym nauczycielem, który winien zająć trzecie miejsce w wychowaniu człowieka po rodzicach i nauczycielach, jak głosił po latach Sebastian Fabian

\footnotetext{
24 Por. Słownik literatury staropolskiej, op. cit., s. 907.
}

$25 \mathrm{H}$. Wiśniewska, pisząc o Klonowicu, wymienia rozprawy na temat wychowania $\mathrm{z}$ drugiej połowy XVI wieku. Mnie interesują jedynie te, których powstanie przypada w okresie poprzedzającym opublikowane Żywota człowieka poczciwego, są to m.in.: O szkołach czyli akademiach ksiag dwoje Szymona Marycjusza z Pilzna (1551), piąta księga De schola Andrzeja Frycza Modrzewskiego (1555), Ksiqż́ki o wychowaniu dzieci barzo dobre, pożyteczne i potrzebne, $z$ których rodzicy ku wychowaniu dzieci swych naukę dołożnq wyczerpnq̨ć mogq Erazma Glicznera (1558), Księgi o wychowaniu i ćwiczeniu każdego przełożonego nie tylko panu, ale i poddanemu każdemu ku czytaniu bardzo pożyteczne Stanisława Koszutskiego (1558), Ksiqżeczki rozkoszne a wielmi użyteczne o pocciwym wychowaniu... dziatek Marcina Kwiatkowskiego (1564). Por. H. Wiśniewska, Renesansowe życie i dzieło Sebastiana Fabiana Klonowica, Lublin 1985, [wyd. II rozszerzone w druku], s. 144-147. 
Klonowic ${ }^{26:}$ Wydaje mi się, że do tego wtaśnie rodzaju nauczycieli można zaliczyć tę mojq ksiqżeczkę, którq stworzyłem $w$ tym przede wszystkim celu [...], abyśmy przekazali potomnym wytyczne naszego życia $w$ czasie pracy i $w$ czasie odpoczynku. Wydaje się, że takie wskazówki zawarł Rej w Żywocie, kreując wzór poczciwego młodzieńca, a zatem człowieka, cechującego się: łagodnym charakterem, uczciwością, dobrocią, przyzwoitością, życzliwością wobec innych, godnego szacunku, potrafiącego właściwie zachować się w każdej sytuacji i wobec różnych osób.

\section{A MODEL OF THE KIND-HEARTED YOUTH IN LIFE BY MIKOLAJ REJ}

\section{Summary}

The aim of this consideration was: first, an attempt at reconstructing the image of kind-hearted youth - based on Life of the kind-hearted man by Mikołaj Rej; second, an arrangement of language forms needed for the writer to influence the reader's way of thinking and behaviour.

Analysing the composition in detail, the authoress concludes that in creation of the worth emulating character, the writer used language forms typical of the persuasive function, i.e. the second person singular; numerous apostrophes; normative statements with modal predicatives e.g. should, ought to, need; directives of significant categorization e.g. order or prohibition; and acts characterized by less categorization e.g. advice, encouragement, hint or suggestion. In addition, the selection of literary genre, i.e. ' the looking glass'; the title of the whole as well as the names of particular chapters; and also recalled exempla - all these influenced the recipient in an incredible way. With the above mentioned language devices, Rej - the teacher, and at the same time Rej - the moralizer tried to create the image of a young man, persuading him to live a kind-hearted life which is virtuous, honest, decent and respectable.

26 Ibidem, s. 144. 